IJSRST

\title{
Soil Analysis and Crop Prediction
}

\section{Shubham Prabhu, Prem Revandekar, Swami Shirdhankar, Sandip Paygude}

Department of Electronics Engineering, KJ Somaiya Institute of Engineering and Information Technology Sion, Maharashtra, India

\section{Article Info}

Volume 7, Issue 4

Page Number: 117-123

Publication Issue :

July-August-2020

\section{Article History}

Accepted : 20 July 2020

Published : 27 July 2020

\section{ABSTRACT}

Soil analysis is an important process to determine the available plant nutrients in the soil. Plants absorb the major nutrients through soil. In addition to soil, there are various major factors like rainfall, precipitation, fertilizer, etc that affect plant growth. Our aim is to create a prediction engine for most suitable crop for a particular soil. As an initial step, we have focused on predicting the accurate crop yield to the user by analyzing the soil fertility and rainfall in the region entered by the user as an input.

Keywords : Soil Analysis, Crop Prediction, Algorithms

\section{INTRODUCTION}

Maharashtrian land consists of non-heritable spread of soil varieties like red soil, black soil, muddy soil and in some regions sandy soil. These completely different soil varieties possess different properties and different fertility levels. Soil fertility is measured by considering the quantity of Nitrogen $(\mathrm{N})$, Phosphorous $(\mathrm{P})$ and Potassium $(\mathrm{K})$ and hydrogen ion concentration in the soil which are needed in comparatively huge quantities. $\mathrm{N}$ is a very important element of all supermolecules, therefore is an integral to the plant. $\mathrm{P}$ may be a minor element of supermolecule, however, is integral to the molecules that manage energy flow among the plant and maybe an element of genetic material. The role of $\mathrm{K}$ appears to be in maintaining the proper salt concentration within the plant sap. Several studies showed that ancient strategies of crop prediction could lead on to poor crop assessment and inaccurate crop space appraisal. additionally, these strategies usually depend on rigorous field information assortment of the crop, that is a costly and time consuming. So, our aim is to come up with an automatic soil testing system which not only will analyze the soil samples but also provide acceptable crop information at free of cost and by consuming less time. This crop prediction is finished by not just considering the fertility of the soil but also by the quantity of precipitation within specific region.

\section{LITERATURE SURVEY}

Research has been carried on agricultural sector using different techniques that can help to solve agriculturalproblems whichhave focused on the most yielding crops. Analysis of the soil is carried out in different regions and sub-regions of Maharashtra.

[2]Based on the nutrient present in the soil, the amount of fertilizers need to be added for better crop prediction is suggested.

[3] Classification between various soil type is performed. For this classification, they have used two 
algorithms: self-organizing map(SOM) and K-means. By comparing these two algorithms they found that SOM has a better accuracy rate as compared to $\mathrm{K}$ means.

[11] various classification algorithms is compared and their accuracy and error rate was checked using the WEKA tool. They applied four different classification techniques on the dataset like J48, LWL, LAD Tree and JBK. Among these four JBK obtained higher accuracy.

[10] study on various different approaches used in Data Mining for crop yield prediction is done. The authors YogeshGandge and Sandhya have summarized various different research papers and the techniques used in those papers by different authors for crop prediction by analyzing the accuracy rate and recommendation.

For crop analysis, we need to monitor various environmental parameters such as temperature, humidity and moisture.

Depending upon this respective parameters overall analysis of the soil is being carried out in this project.Crop selection methodhas been developed for season wise crop prediction.Therefore, based on Kharif(crops which are sown at the beginning of the rainy season, e.g. between April and May.), Rabi(crops that are sown at the end of monsoon or at the beginning of winter season, e.g. between September and October. These crops are known as monsoon crops.)andZaid(short season between Kharif and Rabi season in the months of March to July)the seasonal crops will be predicted. For prediction, they have compared and analyzed different algorithms.One of the main factors that affect crop growth is rainfall.

[7] have considered various parameters: Land evaporation, transpiration, temperature, etc that affect the rainfall. For prediction of rainfall and the water needed by the crop in any particular area, various complex computations have been performed.

\begin{tabular}{|c|c|c|}
\hline TITLE & $\begin{array}{l}\text { METHODS } \\
\text { USED }\end{array}$ & $\begin{array}{l}\text { DESCRIPTION } \\
\text { AND } \\
\text { DEMERITS }\end{array}$ \\
\hline $\begin{array}{l}\text { Analysis of } \\
\text { Soil Properties } \\
\text { and Climatic } \\
\text { Data to } \\
\text { Predict Crop } \\
\text { Yields and } \\
\text { Cluster } \\
\text { Different } \\
\text { Agricultural } \\
\text { Regions of } \\
\text { Bangladesh. }\end{array}$ & $\begin{array}{l}\text { K-means, } \\
\text { PAM, CLARA } \\
\text { and DBSCAN } \\
\text { and four } \\
\text { Linear } \\
\text { regression } \\
\text { methods. }\end{array}$ & $\begin{array}{l}\text { Only four crop } \\
\text { yields have been } \\
\text { considered i.e. } \\
\text { wheat, jute, T- } \\
\text { Ama, and } \\
\text { mustard. }\end{array}$ \\
\hline $\begin{array}{l}\text { Automatic } \\
\text { Soil Nutrient } \\
\text { Detection and } \\
\text { Fertilizer } \\
\text { Dispensary } \\
\text { System. }\end{array}$ & $\begin{array}{l}\text { various } \\
\text { components } \\
\text { including } \\
\text { microcontroll } \\
\text { er, relays, } \\
\text { solenoid } \\
\text { valves, LCD } \\
\text { display, motor } \\
\text { drivers etc. }\end{array}$ & $\begin{array}{l}\text { Hardware is } \\
\text { used to calculate } \\
\text { the soil } \\
\text { properties. }\end{array}$ \\
\hline $\begin{array}{l}\text { Crop } \\
\text { Selection } \\
\text { Method to } \\
\text { Maximize } \\
\text { Crop Yield } \\
\text { Rate using } \\
\text { Machine } \\
\text { Learning } \\
\text { Technique. }\end{array}$ & $\begin{array}{l}\text { Crop Selection } \\
\text { Method was } \\
\text { designed for } \\
\text { crop yield } \\
\text { selection. }\end{array}$ & $\begin{array}{l}\text { The season } \\
\text { required for the } \\
\text { crop is } \\
\text { considered. }\end{array}$ \\
\hline $\begin{array}{l}\text { Analysis of } \\
\text { Soil Behaviour }\end{array}$ & $\begin{array}{l}\text { Naive Bayes } \\
\text { and K-Nearest }\end{array}$ & $\begin{array}{l}\text { The soil } \\
\text { properties }\end{array}$ \\
\hline
\end{tabular}




\begin{tabular}{|c|c|c|}
\hline $\begin{array}{l}\text { and } \\
\text { Prediction of } \\
\text { Crop Yield } \\
\text { using Data } \\
\text { Mining } \\
\text { Approach. }\end{array}$ & $\begin{array}{l}\text { Neighbour } \\
(\mathrm{KNN}) \text {. }\end{array}$ & $\begin{array}{l}\text { suitable for crop } \\
\text { yield are } \\
\text { considered. } \\
\text { Climatic } \\
\text { properties that } \\
\text { affect the crops } \\
\text { are not } \\
\text { considered. }\end{array}$ \\
\hline $\begin{array}{l}\text { Predicting } \\
\text { Rice Crop } \\
\text { Yield Using } \\
\text { Bayesian } \\
\text { Networks. }\end{array}$ & $\begin{array}{l}\text { BayesNet and } \\
\text { Naïve Bayes. }\end{array}$ & $\begin{array}{l}\text { Single crop i.e. } \\
\text { Rice was } \\
\text { considered and } \\
\text { the parameters } \\
\text { considered are } \\
\text { evaporation, } \\
\text { temperature } \\
\text { precipitation, } \\
\text { etc. }\end{array}$ \\
\hline
\end{tabular}

\section{METHODOLOGY}

Specifically, in agriculture new applications, technologies and ways are developed to induce the economical results; to cut down the time and to extend the crop productivity. However, in agriculture, the gathering of such big-data isn't a straightforward task.

For this project, analysis will be done on the soil samples collected from various regions of Mumbai. Currently, five soil samples from different regions is collected and analysis based on termperature , moisture and humidity is carried out at a regular interval of 24 hours and the data is uploaded,displayed and updated at an interval of 2 hours.

All the data analyzed is continuously monitored,displayed and uploaded on the IoT cloud. Thingspeak provides a precise and accurate display of temperature and moisture data.The sensor accuracy and range is also been taken care of, will collecting respective data.

An user friendly application is being designed which would help the customer/user to fulfill their requirements.The designed application will be completely interfaced with the IoT cloud.So in order to provide privacy/security, respective private login creditials are provided. So at the initial stage the user will have to enter the provided login creditials in the application, then the application will check whether the details provided are appropriate with the database. If the details provided are appropriate then access is provided or else ifisis invalid then the login is blocked by displaying "Login Failed" on the main screen.

Then the user can proceed to the next stage (intended application). The required requests of the user are fulfilled by the application where the user sends the request to the application and it checks the database for the intended request and sends the appropriate answer to the application. For eg:- If the user wants to access temperature of a particular soil sample in the region then the user can send request through application to the database demanding for the temperature data of that particular soil sample collected by the hardware circuit and stored successfully in the IoT cloud.

Once all the requirements of the user are fulfilled by the application then the user can logout from the application by simply sending a logout request to the application using logout button provided.

Farmers start to utilize various monitoring and controlled system in order to increase the yield with help of automation of an agricultural parameters like temperature, humidity, soil moisture, soil $\mathrm{pH}$, etc. which can help the farmers to improve the yield. 
Temperature sensor's(DS18B20) output voltage is linearly proportional to the Celsius(temperature). It is rated to operate over a $-55^{\circ}$ to $+150^{\circ} \mathrm{C}$ temperature range.

Soil Moisture Sensor(FC-28) is used for measuring the moisture in soil and similar materials. The sensor has two large exposed pads which functions as probes for the sensor, together acting as a variable resistor

Arduino Uno unit provides base for live monitoring of temperature and soil moisture and sends the data to the cloud via ESP8266 Wi-Fi module. In this IoT product, 2 values are measured: Environmental Temperature, Soil Moisture.

The data will be collected with the help of sensors and data will be first stored in the memory of the Arduino and then with the help of wifi module, data will be wirelessly transmitted to the Iot cloud and then the application.

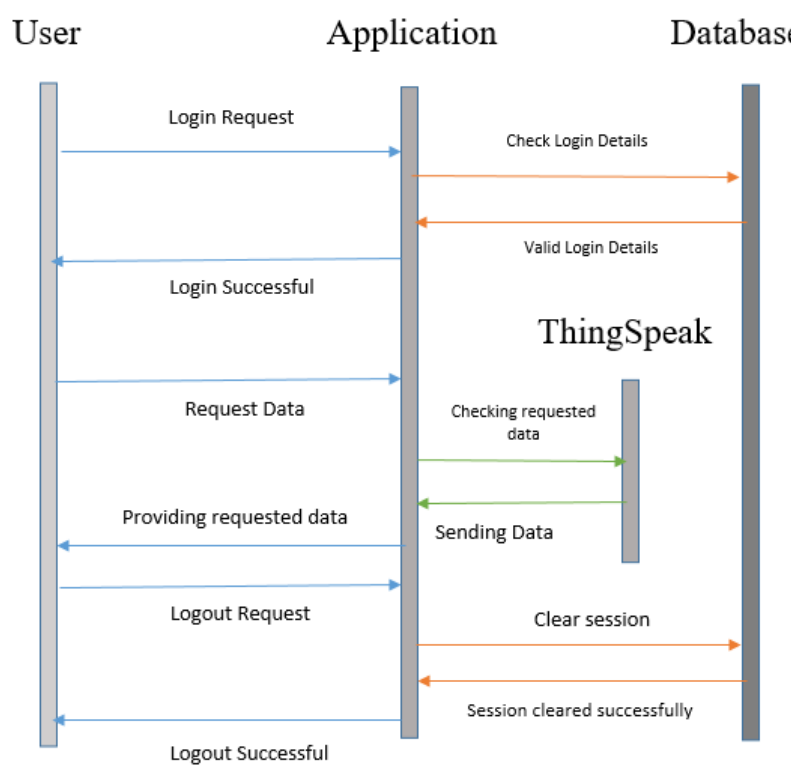

Fig 2: Sequence diagram

\section{RESULT}

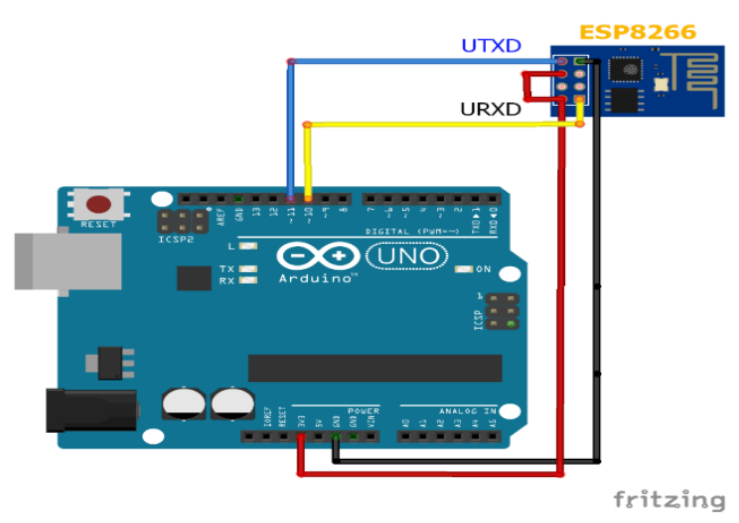

DS18B20 Temperature Sensor is relatively accurate digital temperature sensor and uses MAXIM's 1wire bus protocol for transmitting as well as receiving data in bytes and supports parasite power mode.

The temperature output obtained on the serial monitor as well as on cloud is in Centigrade and depending upon the readings the temperature inside the soil is calculated.

It is observed that the temperature of wet soil isrelativelyvery low when compared to dry soil. Temperature ranges from 20 to $30{ }^{\circ} \mathrm{C}$. Then further for the dry soil the temperature observed is between 30 to $35^{\circ} \mathrm{C}$.

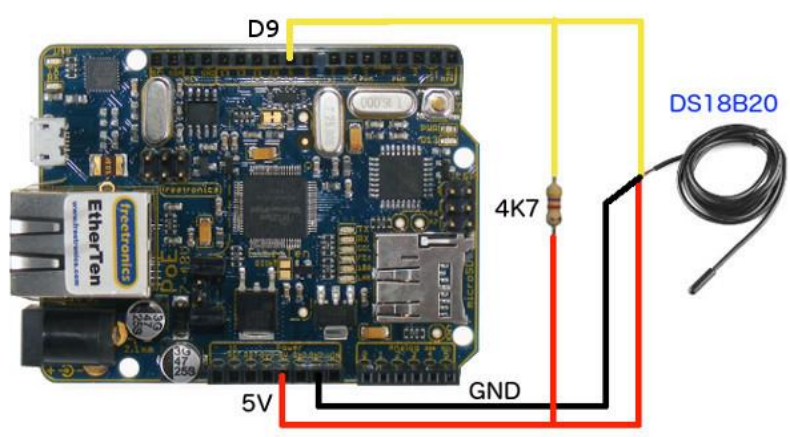




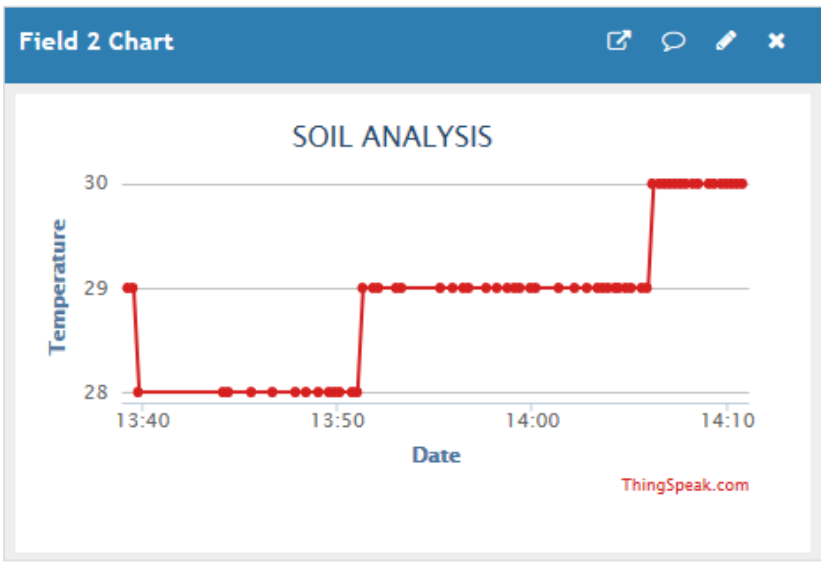

Soil Moisture Sensor works on the resistance changing principle. It has two large pads as probes for the Soil Moisture sensing and also acts as a variable resistor. When water level is low in soil, conductivity is less between the pads and resistance is higher.

For moisture analysis, the output ranges between numbers 0-1000(analog form.). For wet soil the output on serial monitor is between 600 to 694 , depending on this values corresponding graph is plotted on the Iot cloud.

Further, the output being observed is between 300340 for dry soil indicating that the lower the reading lower the moisture content in the soil.

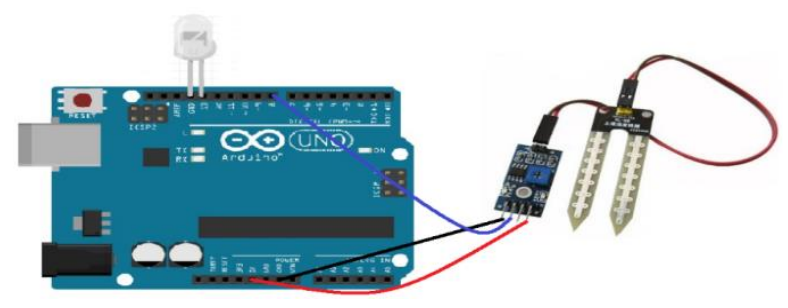

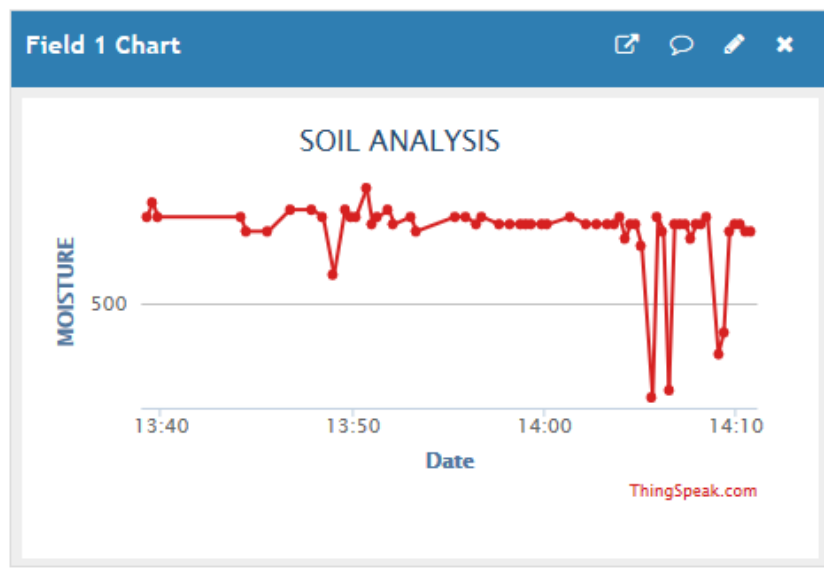

By using the Weka tool, training and testing models were created. Comparison between different algorithms was done. Different algorithms gave different results on the same datasets. The algorithm considered were Logistic, NaiveBayes, and C4.5 and among all three algorithms, the accuracy rate for C4.5 was high. Accuracy and the error rate for each algorithm are shown in Table 3 below.

\begin{tabular}{|c|c|c|c|c|c|}
\hline $\begin{array}{c}\text { Sr } \\
\text { No. }\end{array}$ & Algorithm & RMSE & $\begin{array}{c}\text { RAE } \\
(\%)\end{array}$ & $\begin{array}{c}\text { RRSE } \\
(\%)\end{array}$ & $\begin{array}{c}\text { Accuracy } \\
\text { rate (\%) }\end{array}$ \\
\hline 1. & NaiveBayes & 0.4008 & 76.3472 & 93.5306 & 66 \\
\hline 2. & Logistic & 0.3434 & 62.0915 & 80.1275 & 76 \\
\hline 3. & C4.5 & 0.286 & 46.4722 & 72.3737 & 85.0746 \\
\hline
\end{tabular}

Table 3: Accuracy and Error rate

The Rainfall dataset considered in the project is for the Thane district and it is gathered from different government sites. The rainfall values considered are from the year 2013 to 2018 and for 5 months from June to October. 


\begin{tabular}{|l|l|l|l|r|r|}
\hline District & Taluka & Circle & Year & Month & Rain $(\mathrm{mm})$ \\
\hline Thane & Thane & Thane & 2013 June & 1208.4 \\
\hline Thane & Thane & Thane & 2013 July & 1228 \\
\hline Thane & Thane & Thane & 2013 August & 384 \\
\hline Thane & Thane & Thane & 2013 September & 241.8 \\
\hline Thane & Thane & Thane & 2013 October & 38.4 \\
\hline Thane & Thane & Balkum & 2013 June & 1208.4 \\
\hline Thane & Thane & Balkum & 2013 July & 1028.2 \\
\hline Thane & Thane & Balkum & 2013 August & 511.2 \\
\hline Thane & Thane & Balkum & 2013 September & 250.9 \\
\hline Thane & Thane & Balkum & 2013 October & 35.1 \\
\hline Thane & Thane & Bhaindar & 2013 June & 1208.4 \\
\hline Thane & Thane & Bhaindar & 2013 July & 1052.5 \\
\hline Thane & Thane & Bhaindar & 2013 August & 380.8 \\
\hline Thane & Thane & Bhaindar & 2013 September & 193.6 \\
\hline Thane & Thane & Bhaindar & 2013 October & 109.2 \\
\hline Thane & Thane & Mumbra & 2013 June & 1208.4 \\
\hline Thane & Thane & Mumbra & 2013 July & 1394 \\
\hline Thane & Thane & Mumbra & 2013 August & 359.1 \\
\hline Thane & Thane & Mumbra & 2013 September & 348.4 \\
\hline Thane & Thane & Mumbra & 2013 October & 95.3 \\
\hline Thane & Thane & nahicar & 2012 lune & 12084 \\
\hline
\end{tabular}

Fig 5: Rainfall Dataset

\begin{tabular}{|r|c|c|c|l|}
\hline $\mathrm{N}$ (kg/ha) & $\mathrm{P}$ ( $\mathrm{kg} / \mathrm{ha})$ & $\mathrm{K}$ ( $\mathrm{kg} / \mathrm{ha})$ & $\mathrm{PH}$ & Crops \\
\hline 100 & 45 & 40 & 5.6 & Rice \\
\hline 110 & 47 & 0 & 7.3 & Wheat \\
\hline 89 & 33 & 70 & 5.5 & Jowar(Sorghum) \\
\hline 97 & 40 & 45 & 6.5 & Barley(JAV) \\
\hline 65 & 35 & 0 & 5.5 & Bajra(Pearl Millet) \\
\hline 79 & 35 & 20 & 5.8 & Maize \\
\hline 98 & 41 & 20 & 6.9 & Ragi( naachnnii) \\
\hline 83 & 38 & 80 & 5.9 & Chickpeas(Channa) \\
\hline 67 & 35 & 60 & 6 & French Beans(Farasbi) \\
\hline 62 & 39 & 60 & 6.5 & Fava beans (Papdi - Val) \\
\hline 88 & 37 & 20 & 6.1 & Lima beans(Pavta) \\
\hline 95 & 39 & 25 & 7.3 & Cluster Beans(Gavar) \\
\hline 96 & 40 & 20 & 7.1 & Soyabean \\
\hline 75 & 37 & 0 & 7.4 & Peanuts \\
\hline 79 & 38 & 20 & 5.8 & Black eyed beans( chawli) \\
\hline 85 & 39 & 20 & 6.2 & Kidney beans \\
\hline 82 & 35 & 135 & 5.9 & pigeon peas(Toor Dal) \\
\hline 81 & 40 & 20 & 6.2 & Moth bean(Matki) \\
\hline 95 & 41 & 20 & 7.1 & Mung beans \\
\hline 90 & 42 & 55 & 6.3 & Green Peas \\
\hline 94 & 43 & 20 & 5.9 & Horse Gram(kulthi) \\
\hline
\end{tabular}

Fig 6: Dataset of crop according to Macro-nutrients

This is the testing dataset considered based on the amount of macro-nutrients in the soil and the amount of rainfall for the particular region the crops will be predicted to the user.

\section{v. CONCLUSION}

In this project analysis of soil based on Temperature and Soil Moisture has been proposed using Arduino,
Cloud Computing. The project has high efficiency and accuracy in fetching the live data of temperature and soil moisture. The project will assist the farmers in increasing the agriculture yield and take efficient care of food production as the stick will always provide helping hand to farmers for getting accurate live feed of environmental temperature and soil moisture with more than $99 \%$ accurate results.

The project proposes a wise agricultural model in integration with IoT. IoT have always mattered in Agriculture domain.It is really challenging task because of highly localized nature of agriculture information specifically distinct conditions.The complete real-time and historical environment information is expected to help to achieve efficient management and utilization of resources.

\section{REFERENCES}

[1]. Sadia Afrin, Abu TalhaKhan."Analysis of Soil Properties and Climatic Data to Predict Crop Yields" (2018 IEEE ICIS 2018).

[2]. Amrutha A, Lekha R, A Sreedevi “Automatic Soil Nutrients Detection and Fertilizers Dispensary System" 2016 IEEE International Conference on Robotics: Current Trends and Future Challenges (RCTFC)

[3]. SofianitaMutalib, S-N-Fadhlun, JamianShuzlina Abdul-Rahman, AzlinahMohamed"Soil Classification: An Application of Self Organising Map and kmeans" 2010 IEEE 10th International Conference on Intelligent Systems Design and Applications.

[4]. Singh "Crop Selection Method to Maximize Crop Yield Rate using Machine Learning Technique"2015 IEEE, International Conference on Smart Technologies and Management for Computing, Communication, Controls, Energy and Materials (ICSTM). 
[5]. "Analysis of Soil Behaviour and Prediction of Crop Yield using Data Mining Approach"2015 International Conference on Computational Intelligence and Communication Networks.

[6]. S.Nagini, B.V.Kiranmayee."Agriculture Yield Prediction Using Predictive Analytic Techniques" (2016 IEEE, 2nd International Conference on Contemporary Computing and Informatics).

[7]. Abishek.B, AkashEswar "Prediction of Effective Rainfall and Crop Water Needs using Data Mining Techniques" (2017 IEEE International Conference on Technological Innovations in ICT For Agriculture and Rural Development (TIAR 2017)).

[8]. NiketaGandhi,.. "PredictingRice Crop Yield Using Bayesian Networks" (2016 Intl. Conference on Advances in Computing, Communications, and Informatics (ICACCI), Sept. 21-24, 2016, Jaipur, India).

[9]. YogeshGandge, Sandhya"A Study on Various Data Mining Techniques for Crop Yield Prediction"978-1-5386-2361-9/17/\$31.00 (C)2017 IEEE2017 (ICEECCOT))

[10]. JharnaMajumdar, SnehaNaraseeyappa and ShilpaAnkalaki“Analysis of agriculture data using data mining techniques: application of big data"(2017) 4:20 DOI 10.1186/s40537-0170077-4

[11]. Shruti Mishra, PriyankaPaygude, SnehalChaudhary,SonaliIdate "Use of Data Mining in Crop Yield Prediction"978-1-53860807-4/18/\$31.00 (C2018 IEEEProceedings of the Second International Conference on Inventive Systems and Control (ICISC 2018)

\section{Cite this article as :}

Shubham Prabhu, Prem Revandekar, Swami Shirdhankar, Sandip Paygude, "Soil Analysis and Crop Prediction", International Journal of Scientific Research in Science and Technology (IJSRST), Online ISSN : 2395-602X, Print ISSN : 2395-6011, Volume 7 Issue 4, pp. 117-123, July-August 2020. Available at doi : https://doi.org/10.32628/IJSRST207433

Journal URL : http://ijsrst.com/IJSRST207433 